\title{
Tinjauan Pelaksanaan Review Rekam Medis dalam Rangka Persiapan Akreditasi Rumah Sakit Berdasarkan Standar Akreditasi SNARS-1 di RSUD Sultan Thaha Saifuddin Kabupaten Tebo Provinsi Jambi
}

\author{
Novi Mulyani Putri, Witri Zuama Qomarania, Hosizah \\ Program Studi Manajemen Informasi Kesehatan, Fakultas Ilmu-Ilmu Kesehatan, \\ Universitas Esa Unggul, Jakarta, Indonesia \\ Jl. Arjuna Utara No.9 RT.1/2, Duri Kepa, Kec. Kb. Jeruk, Jakarta Barat, Indonesia \\ Korespondensi E-mail: novimulyaniputri@gmail.com \\ Submitted: 5 Mei 2021, Revised: 23 Juni 2021, Accepted: 28 juni 2021
}

\begin{abstract}
Sultan Thaha Saifuddin Hospital is heading towards the implementation of SNARS-1. The first phase of accreditation in 2016 uses the 2012 version with only four services (SKP, HPK, KPS, PPI) so that there is no medical record review assessment as in the MIRM 13.4 SNARS-1 assessment element. Currently, Sultan Thaba Saifuddin Hospital must adjust the medical record review with the MIRM standard on SNARS-1. Field Study Practices at the Sultan Thaba Saifuddin Hospital, Tebo Jambi Regency on April 1, 2019 to April 20, 2019 with the aim of knowing the implementation of medical record reviews based on the SNARS-1 accreditation standard. Methods of data collection are carried out by observation and interviews using observation sheets and interview guides. The results of the field study practice are: there is a team responsible for reviewing medical records called the medical record committee; there is an SPO regarding medical record review; review of medical records using an open, closed, and recapitulation review form; There was an increase in the quality of medical records based on the results of reviews between period 1 and period 2, namely from $89.65 \%$ to $96.8 \%$ on timeliness, an increase from $95.4 \%$ to $97.6 \%$ in legibility, and an increase from 97, 6\% to 99.2\% on completeness of medical records. The implementation of reviewing medical records at Sultan Thaha Saifuddin Hospital is in accordance with the applicable SPO. The implementation of the review is also in accordance with the SNARS-1 assessment elements.
\end{abstract}

Keyword: medical record, completeness, Accreditation Assessment SNARS-1

\begin{abstract}
Abstrak
RSUD Sultan Thaha Saifuddin sedang menuju implementasi SNARS-1. Akreditasi tahap pertama tahun 2016 menggunakan versi 2012 baru sebatas empat pelayanan (SKP, HPK, KPS, PPI) sehingga belum ada penilaian review rekam medis seperti pada elemen penilaian MIRM 13.4 SNARS-1. Saat ini, RSUD Sultan Thaha Saifuddin harus menyesuaikan review rekam medis dengan standar MIRM pada SNARS-1. Praktik Belajar Lapangan dilakukan di RSUD Sultan Thaha Saifuddin Kabupaten Tebo Jambi pada tanggal 01 April 2019 sampai 20 April 2019 dengan tujuan untuk mengetahui pelaksanaan review rekam medis berdasarkan standar akreditasi SNARS-1. Metode pengumpulan data dilakukan dengan observasi dan wawancara menggunakan lembar observasi dan panduan wawancara. Hasil praktik belajar lapangan yaitu: terdapat tim yang bertanggung jawab pada review rekam medis disebut panitia rekam medis; terdapat SPO tentang review rekam medis; review rekam medis menggunakan form review terbuka, tertutup, serta rekapitulasi; terdapat kenaikan kualitas rekam medis berdasarkan hasil review antara periode 1 dan periode 2 yaitu dari 89,65\% menjadi 96,8\% pada ketepatan waktu, terjadi kenaikan dari 95,4\% menjadi 97,6\% pada keterbacaan, serta terjadi kenaikan dari 97,6\% menjadi 99,2\% pada kelengkapan rekam medis. Pelaksanaan review rekam medis di RSUD Sultan Thaha Saifuddin telah sesuai dengan SPO yang berlaku. Pelaksanaan review juga telah sesuai dengan elemen penilaian SNARS-1.
\end{abstract}

Kata Kunci: rekam medis, kelengkapan, akreditasi SNARS-1

\section{Pendahuluan}

Setiap rumah sakit pasti selalu berusaha untuk meningkatkan mutu dan pelayanannya melalui proses akreditasi. Salah satu manfaat akreditasi bagi rumah sakit adalah guna meningkatkan kepercayaan masyarakat bahwa rumah sakit menitikberatkan sasaran pelayanannya pada keselamatan pasien dan mutu pelayanan. Pelaksanaan akreditasi rumah sakit penting karena dapat mengintegrasikan kualitas pelayanan yang diberikan dan membudayakannya ke dalam sistem pelayanan di rumah sakit sehingga menjadi suatu kebiasaan (1). 
Akreditasi rumah sakit di Indonesia dilaksanakan untuk menilai kepatuhan rumah sakit terhadap standar akreditasi. Sejak tahun 1995, akreditasi rumah sakit sudah mulai dilaksanakan di Indonesia, namun baru mencakup lima pelayanan yang harus dipenuhi. Selanjutnya mulai tahun 1998, jumlah pelayanan yang harus terakreditasi bertambah menjadi 12 pelayanan, dan tahun 2001 bertambah kembali menjadi 16 pelayanan. Namun masing-masing rumah sakit dapat memilih akreditasi untuk 5 (lima) pelayanan, 12 (dua belas) pelayanan atau 16 (enam belas) pelayanan. Dengan demikian, standar mutu rumah sakit dapat berbeda tergantung berapa pelayanan akreditasi yang diikuti. Indonesia memerlukan standar nasional mengenai akreditasi rumah sakit karena status akreditasi yang telah ada terdiri dari status akreditasi nasional maupun status akreditasi internasional. Berdasarkan hal tersebut, maka standar akreditasi untuk rumah sakit yang mulai diberlakukan pada 01 Januari 2018 diberi nama Standar Nasional Akreditasi Rumah Sakit Edisi 1 dan disingkat menjadi SNARS-1. SNARS-1 merupakan standar akreditasi baru yang bersifat nasional dan diberlakukan secara nasional di Indonesia. Disebut dengan edisi ke-1 karena di Indonesia baru pertama kali ditetapkan standar nasional untuk akreditasi rumah sakit (2).

Selain pelayanan medis, penyelenggaraan rekam medis juga menjadi salah satu indikator mutu pelayanan rumah sakit melalui angka kelengkapan pengisian rekam medis. Kelengkapan rekam medis merupakan salah satu faktor yang mendukung keberhasilan program akreditasi karena menjadi salah satu elemen penilaian. Dalam penilaian kelulusan akreditasi rumah sakit, data yang dinilai adalah data mundur. Data mundur untuk penentuan skor 10 (sepuluh) data dikatakan tercapai penuh untuk survei awal adalah data selama empat bulan ke belakang, sedangkan survey lanjutan adalah data selama 12 bulan ke belakang. Untuk skor 5 (lima), data mundur survey awal adalah data 1 sampai 3 bulan mundur ke belakang dan untuk survey lanjutan data 5 sampai 11 bulan mundur. Skor 0 (nol) data mundur 1 bulan ke belakang. Begitu pula untuk kelengkapan dokumen rekam medis, agar mencapai nilai maksimal, maka rumah sakit perlu menyiapkan data mundur sesuai dengan nilai yang diinginkan (3).

RSUD Sultan Thaha Saifuddin yang beralamat di Jl. Sultan Thaha Saifuddin KM.04 Muara Tebo, Kabupaten Tebo, Provinsi Jambi adalah satu-satunya rumah sakit yang berada di Kabupaten Tebo. RSUD Sultan Thaha Saifuddin merupakan rumah sakit umum milik Pemerintah Kabupaten Tebo yang berdiri sejak tahun 2004 dan sampai saat ini masih bertipe C dengan 140 Tempat Tidur, jumlah rata-rata pasien rawat inap 45 orang per hari dan rata-rata pasien rawat jalan 236 orang per hari.

Berdasarkan observasi awal yang dilakukan di RSUD Sultan Thaha Saifuddin, rumah sakit tersebut baru satu kali melaksanakan penilaian akreditasi dengan standar akreditasi versi 2012 pada bulan Oktober 2016 dan lulus dengan hasil akreditasi tingkat Pratama yaitu akreditasi dengan empat pelayanan. Saat ini, RSUD Sultan Thaha Saifuddin sedang dalam tahap persiapan untuk penilaian akreditasi rumah sakit berbasis SNARS-1 yang direncanakan akan dilaksanakan pada bulan Oktober 2019 guna peningkatan standar akreditasi rumah sakit berkelanjutan dan sesuai dengan ketentuan yang berlaku pada saat ini yaitu setiap Rumah Sakit Pemerintah wajib melaksanakan penilaian akreditasi berbasis SNARS1.

Pada penilaian akreditasi tahap pertama dengan standar akreditasi versi 2012 pada tahun 2016 yang lalu, belum ada penilaian terhadap review rekam medis seperti yang terdapat pada elemen penilaian 13.4 MIRM SNARS-1. Penilaian akreditasi RSUD Sultan Thaha Saifuddin hanya sebatas empat pelayanan (SKP, HPK, KPS, PPI) dan belum menjalankan Pokja MKI (Manajemen Komunikasi Informasi). Saat itu hanya dilakukan telusur rekam medis untuk melihat kelengkapan pendokumentasian catatan medis. Untuk saat ini, dimana telah diberlakukannya SNARS-1, maka RSUD Sultan Thaha Saifuddin harus menyesuaikan review rekam medis dengan standar yang berlaku saat ini sesuai dengan elemen penilaian baik itu tata caranya, alat analisis yang digunakan, dan petugas yang melakukan review terhadap rekam medis tersebut. Dari latar belakang diatas, maka penulis hendak melakukan Praktik Belajar Lapangan mengenai pelaksanaan review rekam medis berdasarkan standar akreditasi SNARS-1 di RSUD Sultan Thaha Saifuddin.

\section{Metode Penelitian}

Penelitian ini menggunakan metode penelitian deskriptif dengan pendekatan kualitatif. Lokasi penelitian di RSUD Sultan Thaha Saifuddin Kabupaten Tebo. Pengambilan data dilakukan pada 01 April 2019 sampai dengan 20 April 2019. Metode pengumpulan data dilakukan dengan observasi dan wawancara 
menggunakan lembar observasi dan panduan wawancara. Selanjutnya setelah semua data diperoleh, maka data selanjutnya dideskripsikan menjadi suatu narasi.

\section{Hasil dan Pembahasan}

\section{Gambaran Umum RSUD Sultan Thaha Saifuddin}

Pada tanggal 19 Januari 2004, RSUD Kabupaten Tebo mendapatkan izin dari Direktorat Pelayanan Medik dengan nomor izin IR.01.1.1.231 dan mendapat nomor registrasi 1502013 dengan kelas rumah sakit type C. Kemudian pada tanggal 23 Juli 2004 rumah sakit ini diresmikan oleh Gubernur Provinsi Jambi dengan nama RSUD Sultan Thaha Saifuddin, sehingga mulai saat itu RSUD Sultan Thaha Saifuddin Kabupaten Tebo resmi melakukan pelayanan kesehatan. RSUD Sultan Thaha Saifuddin beralamat di Jln. Sultan Thaha Saifuddin KM.04 Kecamatan Tebo Tengah Kabupaten Tebo Provinsi Jambi.

RSUD Sultan Thaha Saifuddin memiliki luas tanah $10.000 \mathrm{~m}^{2}$ dengan luas bangunan $8.558 \mathrm{~m}^{2}$. Pemilik RSUD Sultan Thaha Saifuddin adalah Pemerintah Kabupaten Tebo yang diwakili Bupati Tebo. RSUD Sultan Thaha Saifuddin telah dinilai dan lulus akreditasi tingkat perdana pada tahun 2016 dan saat ini masih terus mempersiapkan dan membenahi untuk penilaian akreditasi SNARS-1.

Sejak RSUD Sultan Thaha Saifuddin berdiri mulai tahun 2004 dengan nama RSUD Kabupaten Tebo hingga sekarang dengan nama RSUD Sultan Thaha Saifuddin telah beberapa kali mengalami pergantian direktur yang dimulai dari :
a. Pada tahun $2004-2011$ : dr. Agus Fauriza
b. Pada tahun $2011-2013$ : dr. Hendra Gunawan Hilman
c. Pada tahun 2013 - 2016 : dr. Iwan Putra Hutagalung, M.Kes
d. Pada tahun 2016 - 2018 : dr. Ruqoyatul Himah, Sp. A
e. Tahun 2018 - sekarang : dr. Oktavianni, Sp. An

Adapun Visi dan Misi RSUD Sultan Thaha Saifuddin Kabupaten Tebo yaitu:

a. Visi:

Memberikan pelayanan kesehatan rujukan yang prima dan terjanglau oleh semua lapisan masyarakat.

b. Misi:

1) Memberikan pelayanan kesehatan secara professional dan terjangkau pada semua lapisan masyarakat.

2) Meningkatkan sarana dan prasarana RSUD sesuai dengan perkembangan zaman.

3) Meningkatkan kualitas dan kesejahteraan sumber daya manusia RSUD.

\section{Gambaran Umum Unit Kerja Rekam Medis}

Pada awal berdiri rumah sakit, belum ada unit kerja rekam medis. Pelaksanaan rekam medis dilakukan oleh bagian keuangan yang merangkap. Dokumen rekam medis juga baru sebatas lembar rawat jalan dan lembar rawat inap yang hanya terdiri dari ringkasan keluar masuk, catatan dokter, catatan pemberian obat dan vital sign saja. Dokumen rekam medis disimpan berdasarkan abjad nama pasien, serta masih belum ada penomoran pada dokumen rekam medis.

Pada tahun 2008, mulai terbentuk Unit Kerja Rekam Medis di bawah Bagian Umum dan Kepegawaian. Lembar rekam medis semakin bertambah jenis formulirnya dan mulai diberi penomoran rekam medis berdasarkan seri unit dan disimpan dengan sistem terminal digit filing. Rekam medis juga tersimpan secara sentralisasi, dimana penyimpanan rekam medis seorang pasien dalam satu kesatuan baik rawat jalan maupun rawat inap. Unit Kerja Rekam Medis RSUD Sultan Thaha Saifuddin saat ini merupakan unit kerja di bawah Seksi Perencanaan yang teridiri dari 4 orang petugas pendaftaran Poliklinik, 4 orang petugas pendaftaran IGD, 1 orang petugas filing, 2 orang petugas koding dan indeksing, 1 orang petugas assembling, 2 orang petugas pelaporan dan 1 orang Kepala Ruangan.

\section{Penanggung Jawab Pelaksana Review Rekam Medis}

Pelaksanaan review rekam medis di RSUD Sultan Thaha Saifuddin saat ini dilakukan berdasarkan standar akreditasi SNARS-1 dimana terdapat tim yang bertugas dan bertanggung jawab me-review atau menelaah rekam medis. Tim tersebut adalah Panitia Rekam Medis yang telah ditunjuk oleh Direktur 
RSUD Sultan Thaha Saifuddin berdasarkan SK Direktur Nomor 071/Kep/Dir/IX/2018 tentang Panitia Rekam Medis di RSUD Sultan Thaha Saifuddin.

Hal tersebut sesuai dengan hasil observasi di Pokja Akreditasi RSUD Sultan Thaha Saifuddin dimana terdapat dokumen SK Direktur tentang Panitia Rekam Medis dan berdasarkan hasil wawancara dengan Ketua Akreditas dan Kepala Ruang Rekam Medis ketika penulis menanyakan mengenai penanggung jawab pelaksanaan review rekam medis, berikut pernyataannya:
"yang bertanggung jawab untuk telaah sih ada panitia nya. Panitia rekam medis namanya... ndak Cuma orang rekam medis saja isinya... Ada dokter, perawat, gizi pun ada"

Responden 1

Pernyataan tersebut didukung dengan triangulasi yang juga menyatakan:

"Penanggung jawabnya Panitia Rekam Medis, ini ada SK nya... Jadi mereka bertugas mengevaluasi pengisian rekam medis gitu..."

sResponden 2

Panitia Rekam Medis adalah kelompok kerja yang terdiri dari dokter atau dokter gigi atau tenaga kesehatan lain yang terlibat di dalam pelayanan kesehatan dalam rangka untuk memantau dan mengevaluasi mutu pelayanan rekam medis di rumah sakit. Panitia rekam medis di RSUD Sultan Thaha Saifuddin terdiri dari Ketua Panitia seorang dokter spesialis penyakit dalam, wakil ketua seorang dokter umum, sekretaris seorang PMIK, dan anggota panitia terdiri dari 2 orang dokter umum, 1 orang dokter spesialis, 2 orang PMIK, 3 orang perawat, 1 orang apoteker dan 1 orang ahli gizi. Namun dalam pelaksanaan di lapangan, dari hasil observasi selama kegiatan Praktik Belajar Lapangan (PBL) berlangsung, review dokumen rekam medis di RSUD Sultan Thaha Saifuddin hanya dilakukan oleh beberapa orang panitia rekam medis saja, yaitu hanya 1 orang perawat dan 3 orang PMIK.

Hal tersebut juga didukung dengan pernyataan dari hasil wawancara mengenai siapa penanggung jawab review dokumen rekam medis, yaitu: "yaaa.. gitulah kak... panitia nya emang ada beberapa orang, 9 orang apa
ya... tapi yang kerja ya cuma itu itu saja... spesialis ngurusin pasien saja masih
kekurangan waktu, mana sempat lah untuk urusan beginian...."

Responden 1

Dalam rangka menjaga dan meningkatkan kualitas rekam medis maka perlu disusun suatu kelompok kerja atau tim/panitia yang menyusun, mengawasi dan meningkatkan kualitas rekam medis. Panitia Rekam Medis adalah Kelompok kerja yang terdiri dari tenaga kesehatan yang terlibat di dalam pelayanan kesehatan, dalam rangka membantu komite medis agar penyelenggaraan rekam medis bermutu. Dari penjelasan di atas dapat dijelaskan bahwa panitia rekam medis dibentuk oleh Komite Medis (4).

Standar MIRM 13.4 akreditasi SNARS-1 yaitu Dalam upaya perbaikan kinerja, rumah sakit secara teratur melakukan evaluasi atau review rekam medis. Elemen penilaian yang harus dipenuhi pada standar MIRM 13.4.1 adalah rumah sakit menetapkan individu atau tim yang melakukan review rekam medis secara berkala. Hal yang dinilai dari elemen penilaian tersebut berupa ada atau tidak adanya regulasi (R) tentang penetapan tim review rekam medis termasuk pedoman kerja dan program untuk melaksanakan review rekam medis secara berkala (2)(5).

Elemen penilaian standar MIRM 13.4.1 tersebut telah terpenuhi di RSUD Sultan Thaha Saifuddin, dimana telah terdapat SK Direktur Nomor 071/Kep/Dir/IX/2018 tentang Panitia Rekam Medis di RSUD Sultan Thaha Saifuddin. Pada Surat Keputusan Direktur tersebut telah terlampir keanggotaan dan uraian tugas Panitia Rekam Medis. Salah satu dari uraian tugas tersebut adalah monitoring dan evaluasi kebenaran dan kelengkapan dokumen rekam medis. 


\section{Standar Prosedur Operasional Review Rekam Medis}

Selain regulasi tentang penetapan tim review rekam medis, pada telusur elemen penilaian MIRM 13.4 juga dinilai apakah ada pedoman kerja dan program untuk melaksanakan review rekam medis secara berkala (2)(5). Dalam pelaksanaan review rekam medis di RSUD Sultan Thaha Saifuddin mengacu pada Standar Prosedur Operasional (SPO) yang telah diterbitkan oleh direktur pada tanggal 10 April 2018 dengan Nomor Dokumen 041/SPO/AKR.14/IV/2018.

Hasil wawancara yang menanyakan peraturan atau prosedur yang membahas pelaksanaan review rekam medis:

$$
\text { "kita punya SPO nya, itu SPO telaah berkas rekam medis..." }
$$

$$
\text { Responden 1,2 }
$$

Berikut merupakan SPO terkait review dokumen rekam medis di RSUD Sultan Thaha Saifuddin:

$$
\begin{array}{ll}
\text { Judul } & : \text { Review } \text { Berkas Rekam Medis } \\
\text { Nomor Dokumen } & : 041 / \text { SPO/AKR.14/IV/2018 } \\
\text { Nomor Revisi } & : 0 \\
\text { Pengertian : } &
\end{array}
$$

1. Open Review adalah kajian kualitas isi berkas Rekam Medis terhadap pasien yang masih mendapatkan pelayanan di rumah sakit

2. Close Review adalah kajian kualitas isi berkas Rekam Medis terhadap pasien yang sudah selesai mendapatkan pelayanan di rumah sakit

Tujuan:

Menjamin kelengkapan dan kualitas isi berkas rekam medis pasien.

Kebijakan:

SK Direktur RSUD STS Nomor 997/AK/KEP/DIR/2018 tentang Kebijakan Pelayanan Rekam Medis.

Prosedur :

1. Petugas Rekam Medis memilih dari berkas rekam medis pasien (BRM) yang sudah KRS dan pasien yang sedang MRS selama 1 bulan terakhir maksimum 3 hari sebelum rapat review:

a. Ambil BRM dengan DPJP berbeda-beda (DPJPU bila banyak DPJP yang merawat)

b. DPJP yang merawat pasien $<5$ per hari dipilih 1 BRM

c. DPJP yang merawat pasien $5-10$ per hari dipilih 2 BRM

d. DPJP yang merawat pasien $>10$ per hari dipilih 3 BRM

2. Anggota Tim Rekam Medis minimal yang hadir 4 orang dari semua anggota Tim

3. BRM yang terpilih dilakukan pengamatan kualitasnya berdasarkan:

a. Ketepatan waktu pengisian BRM (sesuai ketentuan)

b. Tulisan Profesional Pemberi Asuhan (PPA) dapat terbaca / sulit terbaca / tidak terbaca minimal dilakukan oleh 3 orang yang berbeda

c. Kelengkapan isi BRM:

1) Ringkasan masuk dan keluar

2) Resume medis

3) assessment awal medis

4) Lembar CPPT: Tanggal dan jam, SOAP, Tanda Tangan/Paraf

5) Asesmen kebutuhan pendidikan pasien dan keluarga

6) Informed consent \& Penolakan Tindakan Medis

7) Laporan tindakan: Bedah, Anestesi, Kebidanan, dan lain-lain

8) Edukasi Pasien dan Keluarga Terintegrasi

9) Pengkajian keperawatan

10) Lembar Asuhan Gizi

d. Kelengkapan didata dan diobservasi. 
4. Tim rekam medis melakukan tabulasi hasil data

5. Analisis data

6. Menyusun rekomendasi tindak lanjut

Unit Terkait :

1. Unit Rawat Inap

2. IGD

3. Unit Kamar Operasi

Berdasarkan hasil observasi, pelaksanaan review rekam medis di RSUD Sultan Thaha Saifuddin telah sesuai dengan SPO yang berlaku saat ini dimana telah ada telaah terbuka dan telaah tertutup, review dilakukan oleh 4 orang Panitia Rekam Medis dengan melihat ketepatan waktu, keterbacaan, dan kelengkapan dokumen rekam medis. Panitia rekam medis merekap hasil telaah dan menganalisis serta membuat laporan kepada pimpinan rumah sakit.

Namun pada SPO tentang review rekam medis yang telah diterbitkan tersebut, masih belum terdefinisi dengan jelas/rinci waktu pelaksanaan review rekam medis apakah dilakukan secara berkala ataukah hanya pada saat akan penilaian akreditasi atau dilakukan setiap hari. Sedangkan dalam elemen penilaian yang harus dipenuhi pada standard MIRM 13.4 review rekam medis dilakukan secara berkala. Selain itu, pada SPO belum menjelaskan bagaimana atau apa perbedaan prosedur open review dan close review. Pada prosedur rincian kegiatan yang harus dilakukan belum diuraikan dengan jelas.

\section{Form Review Dokumen Rekam Medis}

Dalam pelaksanaan review rekam medis dibutuhkan form yang digunakan untuk mencatat dan merekap hasil review yang dilakukan. Form yang digunakan untuk review rekam medis di RSUD Sultan Thaha Saifuddin terdiri dari form review terbuka dan form review tertutup. Form review terbuka digunakan untuk me-review rekam medis pasien yang masih dirawat inap. Form ini terdiri dari item tanggal, nomor rekam medis, DPJP, Diagnosa, dokumen yang diminta (form yang di-review), kolom observasi yang terdiri dari tepat waktu, terbaca, dan kelengkapan. Kolom tepat waktu terbagi menjadi kolom ya dan kolom tidak yaitu ya tepat waktu dan tidak tepat waktu. Kolom terbaca juga terbagi menjadi kolom ya terbaca dan kolom tidak terbaca. Sedangkan kolom kelengkapan terdiri dari kolom identitas pasien, tanggal, jam, autentikasi (tanda tangan atau paraf dan nama jelas), assessment setiap hari, TULBAC/Read Back. Hal ini sesuai dengan observasi dan hasil wawancara:

"panduan... kalo panduan itu SPO tadi ndak?

Ooh.. kalo instrument tu mungkin kayak lembar checklist nyo tu dak.. itu ado form nyo macam-macam, ado tigo 1 untuk yang tertutup, 1 untuk yang terbuka, 1 lagi untuk rekapannyo.."

Responden 1

Juga sesuai dengan pernyataan responden ke-2 yaitu:

"review nya pakek lembaran gitu.. itu untuk yang terbuka beda tu.. kalo yang terbuka untuk pasien yang masih dirawat, Cuma beberapa lembar yang dilihat, ndak sebanyak yang tertutup. Kalo yang tertutup tu untuk pasien yang sudah balik.. yang lah sebulan sampe tigo bulan yang lalu lah.. sama ada 1 lagi lembaran untuk merekap persentase lengkap tidak, terbaca tidak, tepat waktu tidak...”

Responden 2

Sedangkan form review tertutup digunakan untuk me-review rekam medis pasien yang telah pulang/keluar rawat inap. Form review tertutup terdiri dari item tanggal, nomor rekam medis, DPJP, Diagnosa, dokumen yang diminta (formulir yang di-review), kolom observasi yang terdiri dari tepat waktu, terbaca, dan kelengkapan.

Perbedaan form terbuka dan form tertutup yang ada di RSUD Sultan Thaha Saifuddin yaitu pada form terbuka kelengkapan lebih dirinci apa saja item kelengkapan yang di-review dan di-review per 
lembarnya. Sedangkan pada form tertutup, review langsung keseluruhan dokumen rekam medis yang diminta yaitu (assesment dan asuhan pasien, ringkasan masuk dan keluar, resume medis, informed consent dan penolakan tindakan medis, laporan tindakan, lembar konsultasi, lembar CPPT (Catatan Perkembangan Penyakit Terintegrasi), lembar serah terima pasien, dan lembar informasi dan edukasi) dengan melihat ketepatan waktu, keterbacaan, dan kelengkapan.

Selain itu, terdapat form hasil rekapan analisis data review rekam medis yang digunakan untuk laporan evaluasi. Form tersebut terdiri dari persentase ketepatan dan ketidaktepatan waktu, persentase keterbacaan dan ketidakterbacaan, serta persentase kelengkapan dan ketidaklengkapan dari seluruh sampel rekam medis yang di-review.

Rekam medis harus di isi dengan jelas, benar, lengkap dan tepat waktu oleh petugas yang berwenang. Disebut jelas jika dapat dibaca oleh setiap orang yang berkepentingan. Benar adalah sesuai dengan bukti diri pasien. Lengkap adalah rekam medis diisi secara lengkap sesuai dengan pedoman tertulis. Tepat waktu adalah penyelesaian/pengisian rekam medis sesuai dengan batas waktu yang telah ditetapkan dalam pedoman tertulis, 2 × 24 jam rekam medis kembali dari ruangan ke rekam medis, 14 hari selesai dilengkapi di ruang perawatan kemudian kembali ke unit rekam medis (6).

\section{Rekam Medis yang Di-Review}

Tidak semua rekam medis di-review mengingat banyaknya rekam medis/banyaknya jumlah pasien tidak sebanding dengan tenaga kesehatan yang ada. Review menggunakan sampel rekam medis yang mewakili. Di RSUD Sultan Thaha Saifuddin, rekam medis yang akan di-review diambil acak per kasus dengan jumlah sampel yang telah ditentukan terlebih dahulu. Jumlah rekam medis yang dijadikan sampel dihitung dari jumlah pasien masing-masing kasus per bulannya. Oleh karena itu, jumlah rekam medis yang di-review akan berbeda-beda setiap bulannya dan setiap kasusnya. Sampel dari tiap bulan di-review per triwulan.

Berdasarkan ukuran sampel bulanan berdasarkan populasi pasien awal yaitu apabila jumlah pasien dalam satu bulan lebih dari 516 orang, maka sampel yang diambil dalam 1 bulan tersebut sebanyak 104 dokumen rekam medis. Apabila jumlah pasien antara 131 orang - 515 orang maka sampel sebesar $20 \%$ dari populasi pasien awal. Apabila jumlah pasien 26 - 130 orang, maka sampel sebanyak 26 sampel, dan apabila pasien kurang dari 26 orang maka seluruh pasien menjadi sampel (7).

Rekam medis yang terpilih menjadi sampel review disimpan per kasus per keranjang di ruang rekam medis sehingga memudahkan melacak dan mencari kembali rekam medis tersebut ketika dibutuhkan atau akan digunakan kembali namun rekam medis tersebut masih dalam proses review. Jumlah pasien rawat inap pada bulan Oktober tahun 2018 sebanyak 136 orang, maka jumlah sampel sebesar 27 rekam medis. Jumlah pasien rawat inap pada bulan November tahun 2018 sebanyak 162 orang, maka jumlah sampel sebesar 32 rekam medis. Jumlah pasien rawat inap pada bulan Desember tahun 2018 sebanyak 138 orang, maka jumlah sampel sebesar 28 rekam medis. Maka sampel rekam medis yang direview pada Januari 2019 sebanyak 87 rekam medis.

Sedangkan jumlah pasien rawat inap pada bulan Januari tahun 2019 sebanyak 178 orang, maka jumlah sampel sebesar 36 rekam medis. Jumlah pasien rawat inap pada bulan Februari tahun 2019 sebanyak 189 orang, maka jumlah sampel sebesar 38 rekam medis. Jumlah pasien rawat inap pada bulan Maret tahun 2019 sebanyak 256 orang, maka jumlah sampel sebesar 51 rekam medis. Maka sampel rekam medis yang di-review pada April 2019 sebanyak 125 dokumen rekam medis.

\section{Pelaksanaan Review Dokumen Rekam Medis}

Review rekam medis di RSUD Sultan Thaha Saifuddin dilakukan oleh Panitia Rekam Medis per triwulan yaitu diawal bulan di triwulan berikutnya (April, Juli, Oktober, Januari). Review dilakukan setiap pagi selama 1 jam di ruang rekam medis menggunakan sampel yang mewakili dengan melihat ketepatan waktu, keterbacaan, dan kelengkapan rekam medis pada rekam medis pasien setelah pulang rawat inap. Sedangkan rekam medis pasien yang masih dirawat di-review oleh perawat ruangan di ruang rawat inap masing-masing. Hasil review tersebut dilaporkan secara berkala pula kepada Pimpinan Rumah Sakit yaitu laporan per triwulan. Sesuai dengan pernyataan responden berikut ini: 


\begin{abstract}
"ngerjainnya sih awal bulan April, awal bulan Juli, awal Oktober, sama Januari tahun depannya untuk telaah pasien triwulan 4.. setiap awal bulan itu, yang 4 orang ini nyisihin waktu kurang lebih 1 jam lah untuk review tertutup di ruang rekam medis sebelum mereka melakukan kegiatan rutin mereka seperti biasa. Kalo untuk detilnya Kepru MR kayaknya yang lebih faham..."
\end{abstract}

Responden 1

Sedangkan pernyataan dari responden 2 yaitu:

"kalo untuk detilnyo, ya dari milih rekam medis yang mau di-review, terus tinggal ngisi form-form yang ada, dilihat/dianalisis lengkap ndak, tepat waktu ndak, terbaco ndak.."

Dari observasi yang dilakukan, hal pertama yang dilakukan untuk review rekam medis tertutup yaitu menentukan jumlah sampel yang akan di-review pada triwulan tersebut. Sampel ditentukan dengan melihat jumlah pasien rawat inap pada setiap bulannya di triwulan tersebut. Selanjutnya memilih dan memilah rekam medis yang akan dijadikan sampel. Sampel diambil dari masing-masing kasus (Penyakit Dalam, Bedah, Kebidanan dan Kandungan, Anak dan Kasus ICU). Rekam medis yang akan di-review dikumpulkan dalam beberapa keranjang per kasus dan disimpan di lemari khusus di ruang rekam medis.

Sedangkan untuk review rekam medis terbuka diambil sampel dengan melihat jumlah pasien yang dirawat DPJD perhari nya. Apabila DPJP yang merawat pasien $<5$ per hari dipilih 1 rekam medis, DPJP yang merawat pasien $5-10$ per hari dipilih 2 rekam medis, DPJP yang merawat pasien $>10$ per hari dipilih 3 rekam medis, dan langsung dilakukan review terbuka setiap harinya. Hasil review terbuka ditempelkan menggunakan kertas kecil dengan diklip di map/sampul dokumen rekam medis untuk segera ditindaklanjuti/diperbaiki.

Setelah sampel terpilih, Panitia Rekam Medis mulai melakukan review rekam medis tertutup di ruang rekam medis dengan menganalisis ketepatan waktu pengisian rekam medis dan ketepatan waktu pengembalian, menganalisis keterbacaan, serta menganalisis kelengkapan pengisian rekam medis hingga seluruh sampel selesai di-review. Selanjutnya merekap hasil review dan membuat laporan serta menyusun rekomendasi tindak lanjut dan mensosialisasikan hasil review serta rekomendasi tindak lanjut tersebut ke pimpinan dan pihak terkait lainnya.

Review rekam medis dilakukan dengan melihat ketepatan waktu yaitu melihat ketepatan waktu pengisian/pencatatan rekam medis, antara lain dengan melihat riwayat penyakit dan hasil pemeriksaan harus sudah lengkap dalam 24 jam setelah pasien dirawat dan sebelum tindakan operasi, tindakan pembedahan dan prosedur lain harus segera dilaporkan setelah dilakukan tindakan paling lambat pada hari yang sama, ringkasan masuk dan keluar serta resume medis sudah harus dilengkapi paling lambat 14 hari setelah pasien pulang. Apabila dalam satu lembar ada yang tidak tepat waktu, maka dikategorikan tidak tepat waktu.

Review keterbacaan dengan melihat setiap catatan yang ada di setiap lembar pada rekam medis, apabila ada yang tidak terbaca atau coretan yang meragukan atau adanya penghapusan dengan menggunakan tip-eks maka dikatakan tidak terbaca.

Sedangkan untuk kelengkapan dengan melihat semua item yang harus diisi pada setiap lembar rekam medis. Bagian yang memang tidak ada isinya harus diberi tanda $\mathrm{Z}$ memenuhi bagian tempat pengisian dengan maksud agar suatu saat tidak diisikan dengan hal yang tidak benar dan tidak sesuai oleh orang yang tidak bertanggung jawab. Apabila terdapat bagian yang tidak terisi dan tidak diberi tanda Z, maka harus dikonfirmasikan kepada yang bertanggung jawab mengisi bagian tersebut. Apabila memang ada yang akan diisi namun tidak diisi maka dikatakan tidak lengkap. Atau apabila ada yang harus diisi namun belum diisikan dan akan diisikan, maka dikatakan tidak tepat waktu pengisian.

Setelah dilakukan telaah, dilakukan tabulasi dan analisis data untuk selanjutnya dilaporkan kepada pimpinan yaitu kepada Komite Medis, kepada Ketua Akreditasi, dan kepada Direktur. Laporan hasil review rekam medis diterima pimpinan untuk selanjutnya dilakukan evaluasi dan tindak lanjut mengenai kelengkapan rekam medis. 
Pelaksanaan review rekam medis di RSUD Sultan Thaha Saifuddin sudah memenuhi elemen penilaian dari standar MIRM 13.4 SNARS-1 dimana review dilakukan oleh Panitia Rekam Medis dan harus dilakukan secara berkala. RSUD Sultan Thaha Saifuddin telah secara berkala yaitu per triwulan melakukan review rekam medis dan dilakukan oleh Panitia Rekam Medis.

Selain itu, review dilakukan dengan melihat ketepatan waktu, keterbacaan, dan kelengkapan sesuai dengan elemen penilaian ke empat dari standar MIRM 13.4 dan menggunakan sampel yang mewakili seperti elemen penilaian 3. Review dilakukan pada pasien yang masih dalam perawatan dan pasien yang telah keluar dari rumah sakit seperti elemen penilaian ke-6. Selanjutnya elemen penilaian 7 juga terpenuhi dimana hasil review dilaporkan secara berkala kepada direktur rumah sakit setiap triwulan.

\section{Hasil Review Dokumen Rekam Medis}

Berdasarkan pengamatan yang dilakukan selama Praktik Belajar Lapangan, diperoleh hasil revien rekam medis dari triwulan ke empat tahun 2018 yang di-review pada bulan Januari 2019 (Periode 1) yaitu dari 87 rekam medis yang menjadi sampel review dan 125 rekam medis sebagai sampel triwulan pertama tahun 2019 yang di-review pada awal bulan April 2019 (Periode 2) yaitu ditampilkan pada Tabel 1.

Tabel 1.

Hasil Review Dokumen Rekam Medis

\begin{tabular}{lcrcrcr}
\hline \multirow{2}{*}{ Rekam Medis } & \multicolumn{3}{c}{ Review Terbuka } & \multicolumn{3}{c}{ Review Tertutup } \\
& Tepat Waktu & Terbaca & Lengkap & Tepat Waktu & Terbaca & Lengkap \\
\hline \multirow{2}{*}{ Periode 1} & $89,65 \%$ & $95,40 \%$ & $78,16 \%$ & $89,65 \%$ & $95,40 \%$ & $96,55 \%$ \\
& & & & & & \\
Periode 2 & $96,8 \%$ & $97,6 \%$ & $94,4 \%$ & $96,8 \%$ & $97,6 \%$ & $99,2 \%$ \\
\hline
\end{tabular}

Dari Tabel 1 tersebut tampak terjadi peningkatan antara periode 1 ke periode 2 baik itu pada fokus ketepatan waktu, keterbacaan, maupun kelengkapan. Peningkatan kualitas rekam medis tersebut dikarenakan hasil review pada periode 1 dilaporkan dan selanjutnya ditindaklanjuti dengan sosialisasi mengenai elemen penilaian MIRM 13.4 yaitu mengenai review rekam medis sehingga dokter, perawat, maupun tenaga kesehatan lainnya yang berwenang mengisi rekam medis semakin meningkatkan kualitas pencatatan pada rekam medis.

\section{Kesimpulan}

Petugas yang bertanggung jawab melaksanakan review rekam medis berdasarkan SNARS-1 di RSUD Sultan Thaha Saifuddin adalah Panitia Rekam Medis yang ditunjuk berdasarkan SK Direktur Nomor 071/Kep/Dir/IX/2018 tentang Panitia Rekam Medis di RSUD Sultan Thaha Saifuddin. Namun hanya tiga orang anggota saja yang aktif dalam pelaksanaan review dokumen rekam medis yaitu 2 orang PMIK dan 1 orang perawat. Prosedur review rekam medis berdasarkan SNARS-1 di RSUD Sultan Thaha Saifuddin telah tertuang pada SPO Review Berkas Rekam Medis dengan nomor dokumen 041/SPO/AKR.14/IV/2018, namun prosedur pelaksanaan pada SPO tersebut belum mendefinisikan dengan jelas langkah-langkah review terbuka maupun review tertutup. Review rekam medis dilakukan dengan menggunakan form telaah terbuka untuk pasien yang masih dirawat inap dan form telaah tertutup untuk rekam medis pasien yang telah keluar/pulang rawat inap, serta direkap pada satu form hasil analisis. Hasil Review rekam medis di RSUD Sultan Thaha Saifuddin Kabupaten Tebo antara periode 1 dan periode 2 yaitu terjadi kenaikan 7,2\% dari $89,65 \%$ menjadi $96,8 \%$ rekam medis yang tepat waktu, terjadi kenaikan $2,2 \%$ yaitu $95,4 \%$ menjadi $97,6 \%$ pada keterbacaan rekam medis, serta terjadi kenaikan 1,6\% untuk kelengkapan rekam medis yaitu dari $97,6 \%$ menjadi $99,2 \%$. 


\section{Daftar Pustaka}

1. Kars S, Pada V, Manajemen S. Tinjauan Pelaksanaan Komite Akreditasi Rumah Sakit (KARS) versi 2012 Pada Standar Manajemen Komunikasi Informasi (MKI) 8 di RSU Sufina Azis Medan Tahun 2016. 2017;(1):200-6.

2. Komisi Akreditasi Rumah Sakit. Standar Nasional Akreditasi Rumah Sakit Edisi-1. 1st ed. Prof. Herry Garna, editor. Jakarta Selatan: Komite Akreditasi Rumah Sakit; 2017.

3. Komite Akreditasi Rumah Sakit. Standar Akreditasi Rumah Sakit versi 2012 [Internet]. Komisi Akreditasi Rumah Sakit. 2012. 1-421 p. Available from: http:/ / akreditasi.kars.or.id/downloads/RS-Template.xls

4. Akasah. Pengelolaan Sistem Rekam Medis I (PSRM I). Bandung; 2008.

5. Kemenkes. Instrumen-Survey-Akreditasi-Rs-Snars-2018.Pdf. 2018. p. 295.

6. Hatta GR. Pedoman Manajemen Informasi Kesehatan di Sarana Pelayanan Kesehatan. Revisi 2. Jakarta: Universitas Indonesia; 2010.

7. https://manual.jointcommission.org/releases/TJC2018A/Sampling ChapterTJC.html 